"This is an Accepted Manuscript of an article published by Taylor \& Francis in Theology and Science on 02 Sep 2017, available

online: http://www.tandfonline.com/doi/abs/10.1080/14746700.2017.1369760?journalCode=rtas 20." Free copies of the final publication can be downloaded by the first 50 people from here: http://www.tandfonline.com/eprint/gjWNX7ysGrvXaqmg8I3y/full

\title{
A Theological Cartography of Cultural Evolution
}

Mapping the Ramifications of Cultural Evolution for Christian Faith

Christopher M. Hays

Michael S. Burdett

\begin{abstract}
This article maps key points of contact between Christian doctrine and recent advances in cultural evolution. Beginning with theological anthropology, the article shows that cultural evolution problematizes purely substantive accounts of the image of God. Moving to the doctrine of sin, we explain how cultural evolutionary findings enrich and challenge distinct aspects of hamartiology. The article turns to moral topics, since cultural evolution sheds light on altruistic and hypersocial behavior; additionally, we show how belief in moral deities and observation of religious rituals provide an evolutionary advantage. Finally, the authors analyze whether cultural evolution amounts to an explanation of religion.
\end{abstract}

\section{Keywords}

Cultural evolution, theological anthropology, hamartiology, morality, altruism, ritual

\section{Introduction}

Ancient maps are entertaining for modern observers, not primarily because of what the cartographer knew, but because of what s/he did not know. Medieval maps are especially intriguing in this respect, with their floppy and misshapen continents, completely lacking the Americas, Australia, and Antarctica. On those yellowed parchments, the oceans are frequently embroidered with fantastic sea creatures, and at the edges of the maps, in regions little-known to explorers of that era, medieval cartographers would sometimes pen the phrase hic sunt dracones ("here be dragons"). It was the cartographer's way of saying, "This land or sea is unknown, savage, dangerous-best left alone."

On the theological maps of $20^{\text {th }}$-century Christianity, the regions of cosmology and evolutionary biology were often annotated with hic sunt dracones, vel diaboli, 
although the past two decades witnessed a surge of engagement between faith and modern science. Nonetheless, even after students of Christianity come to terms with better-known scientific topics, when they venture to explore a new field of science, the tendency is to wonder whether in this unknown terrain there might dwell theological dragons, if not devils.

In the past 20 to 30 years, scientific research has advanced in the field of "cultural evolution."i While intrepid scientists are exploring its topography, theological scholarship on the most recent findings is still limited. We propose to fill this gap and provide a "theological cartography" of contemporary cultural evolution, stimulating more robust theological engagement therewith by mapping the parts of cultural evolution that are pertinent, poignant, or perilous for Christian doctrine. ${ }^{\text {ii }}$

We begin by providing a brief overview of the findings in the field of cultural evolution that are relevant for theology. On that basis, we will explore the ramifications of cultural evolutionary insights for theological anthropology (particularly for the image of God) and hamartiology (the doctrine of sin). The topic of sin will open up broader questions of morality (specifically, regarding altruism and hypersociality). Finally, we will examine whether religious rituals and the fundamental belief in God might merely be byproducts of cultural evolution.

\section{A Summary of Cultural Evolution}

Most popular conceptions of evolution focus solely on the genetic level of evolutionary change at the expense of extra-genetic factors involved in natural selection. This has been so since the 1930s and 1940s, when the insights of population genetics were integrated into Darwin's account of natural selection - "the preservation of favourable individual differences and variations, and the destruction of those which are injurious" iii - as the engine of evolutionary change. Since then, genes have been considered the primary factors in population changes.

There now exists a considerable movement to redress the focus on the change of gene frequencies over time. ${ }^{\text {iv }}$ Beginning in the 1970s, advances in embryology and molecular genetics made clear that phenotypic variation is not solely based on differences in genes, but very often on the same genes being expressed or not. Thus, evolutionary developmental biologists ("evo-devo") insist that the regulation of genetic expressions has been neglected in the Modern Synthesis's account of evolutionary change. In particular, molecular geneticists argue that epigenetic factors-cell activities that modify genetic activation - play a significant role, not just in organismic functioning and development, but also in evolution as these factors are also heritable across generations. Then, in the 1980s, ecologists, ethologists, and anthropologists began challenging the account of evolutionary change that posited organisms are not solely 
passive with respect to their genetic inheritance-surviving only at the mercy of congruence, or the lack thereof, between their inherited traits and the environment. Rather, according to niche construction theorists, organisms "co-construct and co-evolve with their environments, in the process changing the structure of ecosystems". v

Just in the past few years, some evolutionary theorists have called for an extended evolutionary synthesis to integrate the discoveries and insights from developmental biology, molecular genetics, ecology, and ethology. On the latter point, human ethology - the study of human behavior-has also become increasingly represented among evolutionary theorists. It is from this angle that the evolution of culture has received more prominent attention in recent years. Culture, it has been argued, also evolves in a Darwinian fashion, ${ }^{\text {vi }}$ not only that, the evolution of culture itself contributes to biological evolution via cultural niche construction. ${ }^{\mathrm{vii}}$

The evolution of culture is not a recent arrival on the scientific scene. In The Descent of Man, Darwin discussed the "inherited habits" progeny acquired from parents; he also referred to "customs," "education," "laws," and "public opinion" to explain the evolution of societies. viii But today more than ever, extra-genetic mechanisms are recognized to play a critical role in the evolutionary process. Therefore, theologians ought to engage with recent findings in cultural evolution, because it is increasingly becoming a major player in our understanding of evolution as whole.

What is cultural evolution? Alex Mesoudi defines culture itself as "Information that is acquired from other individuals via social transmission mechanisms such as imitation, teaching, or language", further specifying that the "information" in question refers to "knowledge, beliefs, attitudes, norms, preferences, and skills". ix Culture is, then, simply the store of knowledge, practices, and norms for a given social group.

Culture evolves because it is a kind of "inheritance system": we do not receive only our genetics from our parents, but are educated by them and by others in our communities; and the cultural traits we adopt give us a relative selective advantage in our environments. For example, a young chimpanzee might learn from its mother to select and prune a thin stick to access safari ants deep inside their colony. This cultural adaptation will help the young chimp survive because it means they will have access to a consistent food supply and will be able to reach sexual maturity. So, a culturallytransmitted practice can produce a selective advantage.

Cultural evolution largely depends on two major forces: innovation and social transmission. ${ }^{x}$ Innovation refers to the ability of a single individual or set of individuals within a society to develop a novel practice or tool relative to shifting ecological changes. These innovations can come about through fortuitous circumstances (like Alexander Fleming discovering mold on his petri dishes, which led to the manufacture of penicillin) or direct rational reflection on the task or norm that seeks intentionally to make the practice or tool better. ${ }^{\text {xi }}$ Innovation can be the beginning of cultural revolution. 
But innovations need not lead deterministically to radical cultural change, because the innovation needs to be transmitted to others in the society for such upheaval to occur.

How does selection function at a cultural level? One might think that if one tool or practice were more efficient than another, it would spread quickly throughout a group, but it need not do so. The nature of social transmission helps to explain why some things catch on and lead to cultural change and others do not. Major contributing factors include: (1) the nature of the teaching/learning process (Is it directed and explicit or is it caught by observation?), (2) how cooperative the society happens to be (Is it more or less altruistic?), (3) the existing norms and rituals that are operative for a given social group (Are there existing norms or rituals that might clash with or enhance/dovetail with the new cultural practice or tool?) and (4) the functional novelty of the new cultural practice or tool (Does the practice or tool better complete the intended aim than others available?). This is a list of just some of the possible influencing factors that lead to cultural evolution.

Having sketched the contours of current thinking on cultural evolution, we can proceed to fill in the map, explaining how Christian theology might relate to or be affected by these advances in scientific knowledge.

\section{Theological Anthropology}

We begin by outlining the ramifications of cultural evolution for theological anthropology, specifically focusing on what it means for humans to be "the image of God". J. Wentzel van Huysteen and others have made significant strides in relating theological anthropology to the evolutionary sciences, including cultural evolution. ${ }^{\text {ii }}$ One of the most significant features of this dialogue concerns human distinctiveness. Van Huysteen locates such distinctiveness in relational terms and in the human symbolic, linguistic, and imaginative capacities. Joshua Moritz contends the distinctive feature that grounds the image of God is a particular kind of relationship to which God calls and elects humans. Philip Hefner avows similar distinctive features and adds to them the culturally creative capacity of human beings. Indeed, many recent theologians and Christian thinkers prefer to construe human distinctiveness in terms of cultural markers rather than exclusively emphasizing genetic attributes. They have good reason to do so; given that human beings share upwards of $98 \%$ of their DNA with their closest primate relatives, genetics does not seem sufficient to ground the distinctive claims inherent in the image of God.

Scientists themselves are increasingly discovering that our cultural differences from other animals contribute decisively to human uniqueness. For example, some research explains that advances in human culture and knowledge over those of other higher primates are due, in significant degree, to mechanisms such as: the higher degree 
to which humans imitate (paying attention to processes), rather than just emulate (focusing exclusively on outcomes), and the extent to which we innovate, teach, and function cooperatively in the pursuit of common goals. Scientists such as Michael Tomasello indicate human culture is "cumulative" in a way no other animal culture approximates. ${ }^{\text {xii }}$ This means that successive generations of humanity build on the innovations and stores of knowledge of the previous generation, accumulating over time in ways that allow a "ratcheting effect": preventing successive generations from losing the cultural knowledge of the past generation, and enabling them to improve upon that knowledge. Even the most sophisticated ape cultures (in captivity and in the wild) do not exhibit such advanced "cumulative culture".

We are not, however, saying that our way of functioning is for the most part qualitatively different from that of other apes; they still imitate to varying degrees, they still teach to varying degrees, they still cooperate, they have many unique traditions (culture) which they transmit distinctly, they have rudimentary capacity for language, they solve problems, etc. We are different from the other apes by degrees, not just genetically but in the way we function culturally, and those degrees of difference are key factors in making us distinctively human.

Cultural evolution fleshes out further what is distinctive about human reasoning. ${ }^{\text {xiv }}$ Instead of simply emulating modeled behavior insofar as we understand how an action results in a given outcome, we "over-imitate", repeating causally opaque processes, which enables us to perform complex actions even if we do not understand why they work. ${ }^{x v}$ Humans also innovate in higher degrees than do other apes, meaning that we can build further on causally opaque processes to establish ever-more complex procedures. Moreover, the human tendency to over-imitate is embedded in an orientation towards sociality: our capacity for teaching and social learning, as well as our sensitivity to group norms and conformity, make us far more inclined to overimitate others and to capitalize on the innovations in our groups. Likewise, our tendency for extreme cooperation beyond the limits of kinship-based altruism ensures higher levels of learning from multiple sources and maintains higher levels of fidelity in the transmission of information across generations. While most of these characteristics can be identified in attenuated ways among other apes, their quantitative intensity and simultaneous operation in humans actually makes our human brand of reasoning uniquely productive.

Even with this nuanced apprehension of how humans reason in unique ways, the lack of categorical qualitative distinctions between our reasoning and other animals' reason should make us wary of a purely "substantive" anthropology, which identifies the human intellect and rationality with the image of God (pace e.g. Augustine, Trin. 13.4.6; 13.7.10-8.11; Aquinas, ST I Q. 93, Art. 2, 4). That is not to say that reason is irrelevant to our being the image of God. The present authors are inclined towards a relational and functional theological anthropology, ${ }^{\text {,vi }}$ but there is little doubt that our 
creative and rational faculties play key roles in our capacity to function as God's image. Accordingly, we would not exclude all "substantive" features of theological anthropology; one simply ought to recognize the pitfalls of locating human theological distinctiveness in putatively qualitative differences between us and other apes. The human sort of reasoning is special and enables us to be the image of God, but it does not exhaust what it means to be God's image.

In this regard, we agree with Aku Visalaxvii that contemporary strategies which short circuit any substantive or structural talk when incorporating evolutionary findings into the conception of the human being simply fail to appreciate how important substantive features are to other models of the imago Dei. For example, a functionalist account of theological anthropology will focus on the vocational responsibility of humans to serve as God's representatives in the world, especially on the basis of Genesis 1:26-28; the logic of Gen. 1:26-28, however, depends irreducibly on the physical presence and operations of humans qua God's representatives, suggesting that humans' unique role in the world cannot be separated from their distinctive physicality. ${ }^{\text {xviii }}$ A similar challenge obtains for relational accounts of theological anthropology, which argue that the image of God consists of the distinct relationship human beings have with God. For such a relationship to be possible, the human being must possess certain relational capabilities (e.g., a robust theory of mind). Therefore, even though cultural evolution corroborates the case for functional and relational models of the image of God, one ought not to exclude attention to features typically foregrounded by structural theological anthropologies.

\section{Cultural Evolution and the Doctrine of Sin}

The cultural-evolutionary dynamics of over-imitation, learning, and conformity do not simply support the transmission of technical knowledge; indeed, these dynamics are likely to propagate a wide variety of actions and beliefs. This observation is of no little importance for the Christian doctrine of sin and, therefore, comprise an entire "continent" in our theological cartography of cultural evolution.

It is nothing new to discuss how evolutionary theory influences our understanding of sin. Some have identified the evolutionary biological impulses towards reproduction, self-preservation, and violence as accounting for human sinful behavior. On this construal of things, human lust or selfishness or murder are largely part of our biological inheritance. ${ }^{\text {ix }}$ Humans remain moral agents responsible for how they respond to these biological impulses, but biological evolution contributes to our moral corruption.

Without denying the biological contribution to humans' immoral inclinations, cultural evolution adds texture and nuance to our understanding of human sinfulness. 
Benno van den Toren has pointed out the connection between sinful inclinations and the human penchant for over-imitation and our tendency to conform to our parents and educators. ${ }^{\mathrm{x}}$ If human parents are given to behaviors which are sinful, it follows that the next generation would replicate that behavior and even innovate upon it, as a sort of hamartiological ratchet effect. This description of the evolutionary dynamics of sin fits neatly with the classical doctrine of sin as a moral corruption: biological and cultural evolution strongly incline us towards sinful behavior, per the doctrine of concupiscence (e.g. the "sin nature", which affirms that the human volition is corrupted and thus inclined to sin), but they do not necessitate that we sin in any given scenario. Thus, humans are morally responsible for their sins, even though their biology and susceptibility to cultural transmission of sinful behaviors mean that, given sufficient time, they will certainly sin voluntarily (in other words, non posse non peccare).

Locating the origin of human sinful impulses in biological and cultural evolutionary dynamics does problematize the traditional narrative according to which the sin of Adam and Eve (the "originating sin") gave rise to all subsequent sin. In spite of the fact that cultural evolution helps explain the rise of (proto-)virtuous behaviors such as altruism and hypersociability, it also sheds light on the origins of our violent, sexually promiscuous, and selfish actions, since those same behaviors are present in e.g. chimps and monkeys. ${ }^{x \times i}$ While one would not impute sinful status to behaviors such as killing or sexual promiscuity when they are performed by non-human animals (assuming that moral awareness and therefore culpability are unique to humans and perhaps to some now-extinct hominids), genetics and cultural evolution would indicate that the human propensity towards those same actions does indeed owe, at least in part, to our evolutionary heritage. In other words, humans have an inclination to, e.g., kill their enemies because our common ancestors with chimps also had the same inclination, which was then transmitted to us via both genetic and cultural evolutionary mechanisms.

\section{Concupiscence without the Originating Sin or Original Guilt?}

This narrative of the origin of sinful propensities is largely compatible with the doctrine of concupiscence, ${ }^{\text {xxi }}$ but it problematizes the traditional construal of an originating sin (peccatum originans), according to which the corruption of the will is traced to the single originating sin of Adam. If the propensity towards sinful behavior predates the rise of humans, then concupiscence cannot be laid at the feet of Adam (or of the first morallyconscious human to sin). While human tendencies towards over-imitation and conformity would have contributed to contemporary humans imitating the example of the first morally-conscious sinner, those same dynamics would have been previously operative, as non-morally-conscious hominids observed and imitated behavior that would be sinful for morally-conscious hominids. In other words, the first sin should not 
necessarily be considered the origin of all $\sin$ (i.e. the originating $\sin ^{x \times i i i)}$; while there must logically have been a first instance of a morally-conscious being committing a sinful action, that same action would have been previously committed any number of times by non-morally conscious beings (whose commission of the action cannot be described as sinful, insofar as moral awareness is prerequisite to culpability). So, while one can maintain belief in the dynamics of concupiscence, the traditional construal of a single originating sin qua the source of concupiscence is difficult to square with this evolutionary account of the origins of human sinful behavior.

Once the conception of a single originating sin is precluded, another component of the dominant western doctrinal theory of sin would be problematized: original guilt. The notion of original guilt holds that all humans share in the guilt of the originating sin, meriting damnation (even apart from their own personal commission of sins) because of what Adam did. If, however, there was no originating sin, then original guilt would become a moot point, for one could not be guilty of an originating sin that never was.

Nonetheless, this incompatibility between biological and cultural evolution and the theory of original guilt is not as theologically problematic as one might surmise at first glance. While the idea of original guilt is common in Western Christianity, it is not a universal Christian commitment (for example, it does not figure into the 39 Articles of the Anglican Church, nor is it present in Eastern Orthodox doctrines of sin). Indeed, the belief itself is arguably morally problematic, insofar as the notion of being damned for the decisions of a distant progenitor offends against most notions of justice. ${ }^{x i v}$ The idea is nowhere explicitly affirmed in the biblical corpus and rose to prominence largely on the basis of a misreading of Romans 5 by Augustine of Hippo. ${ }^{x x v}$ All that is to say that an exclusion of the notion of original guilt would not be tantamount to the rejection of the doctrine of $\sin . x \times v i$

Alternative Approaches to the Originating Sin

One could nonetheless conceive of other ways to adjust the traditional construal of originating sin to fit with the emerging data on biological and cultural evolution. One could perhaps argue, along the lines of the federalist approach to the doctrine of $\sin$, ${ }^{\text {xvvii }}$ that God constituted the first spiritually- or morally-conscious hominid to be the representative, the "federal head", of the rest of the species, such that, when that representative figure sinned, the rest of the species was morally implicated in the action of their representative. In other words, one could decouple the idea of original guilt from the notion of an originating sin, and connect original guilt simply to the first sin, by-passing the logic of a common progenitor that was operative in constructing the Augustinian notion of original guilt (insofar as Augustine's argument emphasized that 
sin passed from Adam to the rest of humanity because of natural descent from Adam; Augustine, Pec. merit. 9).

Alternatively, one might suggest that the originating sin does not function as the source of concupiscence, but as the fountainhead of moral awareness. In this scenario, the watershed moment for sin was not the first commission of a cruel or selfish action, but the commission of that action by the first morally-conscious human. Perhaps what that human then transmitted to other humans was not a sinful tendency, but a moral awareness that their previously-existing tendencies were sinful. While this is not the typical way of construing the idea of originating sin, some theologians might find it attractive insofar as it has plausible connections to the Genesis 2-3 narrative: in that account, the first sin is eating of the tree of knowledge of good and evil, after which Adam and Eve are morally aware (Gen. 3:1-7, 22). One might want to make additional connections to Pauline teachings about how the Law (as a source of greater moral awareness), under the influence of sin, generates a greater propensity towards sin (Rom. 7:7-25); by this token, one could argue that the transmission of moral awareness via cultural evolution helps sharpen concupiscent impulses, operating much like the Law does in Pauline theology. Finally, this approach would permit theologians to maintain the idea of a single sin which was the source of all other sins, without running afoul of scientific advances on the origins of human inclinations towards deeds which are sinful for morally-aware beings.

The present authors may not consider either of these alternative approaches compelling, but the purpose of the present essay is not to posit a definitive theological stance vis-à-vis any particular feature of cultural evolution. The point is rather to emphasize, on the one hand, that cultural evolution can add depth to the Christian understanding of sin. On the other hand, theologians should be aware that cultural evolution does have an impact on some traditional versions of the doctrinal theory, although it hardly forecloses the possibility of any number of robust accounts of the doctrine of sin.

\section{Cultural Evolution and Morality}

\section{Altruism, Hyper-sociality, and God-of-the-Gaps}

This discussion of original sin reflects the tendency of Christian theologians to fixate on the consequences of evolutionary theory for immoral human behavior. Nonetheless, evolutionary theory in general and cultural evolution in particular have ramifications for our understanding of human virtues, such as altruism, and make up some of the most fascinating "rivers" and "mountains" on the present theological map. The fact that humans behave altruistically has often been considered problematic for 
conventional construals of evolution; in The Descent of Man, Darwin himself recognized that altruistic behavior created wrinkles for his theory. "red in tooth and claw" and favors those attributes that conduce to reproduction, it would stand to reason that those animals which were most selfish would be most likely to reproduce and pass on whatever genetic traits that contributed to their selfishness. Conversely, if an animal had an impulse to sacrifice its food or life for the good of another animal, such an animal would be less likely to reproduce, as a consequence of which it would be less likely that the genetic traits which contributed to their altruism would be propagated. Natural selection, it seemed, ought to favor not just the fittest, but the most selfish organism.

Of course, humans regularly function in ways that are dramatically altruistic. Most parents would risk or sacrifice their lives to save their children; does this not belie the hegemonic claims of natural selection? Probably not. Evolutionary biologists refer to this as "kin selection." It is entirely coherent with natural selection that one would behave altruistically towards one's offspring, insofar as doing so contributes to the success of one's reproduction. English evolutionary biologist W.D. Hamilton formulated this principle in what is called Hamilton's Rule, arguing that the likelihood of a person's willingness to risk their life on behalf of another is directly related to the

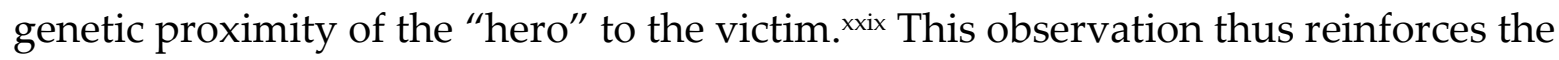
typical construal of natural selection.

Nonetheless, the morning news (less so than the evening news) is full of stories about the selfless actions and sterling heroism of social workers, soldiers, and firefighters in the service of strangers. Such "supererogatory" altruism is not entirely uncommon, and some have suggested that it is difficult to explain such non-kinshipbased altruism by appeal to evolutionary biology and reproductive fitness.

For example, Francis Collins argued that God operated against the grain of natural selection in order to produce human altruism. Collins is no enemy of evolutionary theory, but he sees the divine hand in the supposedly evolutionarilyimprobable actions of human altruism.

Agape, or selfless altruism...cannot be accounted for by the drive of individual selfish genes to perpetuate themselves. Quite the contrary: it may lead humans to make sacrifices that lead to great personal suffering, injury, or death, without any evidence of benefit. ${ }^{\mathrm{xxx}}$

Collins explained that this altruistic inclination so defies evolutionary impulses that it exposes a serious vulnerability in atheistic accounts of evolution and strongly suggests a divine origin. ${ }^{\times x i}$

Collins came under fire for this sentiment, insofar as he seemed to appeal to a "God of the Gaps", xxxii a strategy against which he had rightly cautioned Intelligent Design advocates. ${ }^{x x i i i}$ The concern with this line of argumentation is that, if someone 
should be capable of explaining how altruism did not amount to a reproductive disadvantage, God would be squeezed out of the altruistic gap. ${ }^{\text {xxiv }}$

Cultural evolution may provide precisely the wedge needed to eject the altruistic gap-dwelling God, insofar as it explains that natural selection does not only operate at the level of the organism or the family. Kin selection, group selection, ${ }^{\mathrm{x} x \mathrm{v}}$ and cooperation have proven highly effective in giving humans a collective survival (and therefore reproductive) advantage. Through hyper-sociality (e.g. cooperative hunting and child-rearing, protection against predators and rival groups, etc.), humans have gained an edge over against stronger, faster non-human animals. As such, the genes that conduce towards cooperative behavior would be more likely to spread; alternatively, genes conducing towards non-cooperative behavior would generate a reproductive disadvantage, insofar as such people would more often be excluded from cooperative communities. So, insofar as the sorts of impulses that facilitate cooperation seem highly analogous to the impulses that stimulate altruism, it stands to reason that altruism, even beyond the boundaries of kin-relations, does not amount to a net reproductive disadvantage.

\section{Hyper-Sociality and Moral Deities}

Cultural evolution not only explains the human tendency for moral and immoral behavior; it also helps account for our belief in morally-attentive deities. There is evidence to suggest that belief in a morally-attentive deity provides a survival benefit in larger groups, where kinship-based altruism is no longer operative. ${ }^{x x x v i}$ For example, humans are less likely to cheat one another and more likely to engage in generous activities when prompted to think of a watchful deity. ${ }^{\text {xxvii }}$ Similarly, religious people are more inclined to treat their co-religionists fairly if their religion includes a moralistic and punitive deity. ${ }^{\text {xxviii }}$ All this might suggest that cultural evolution played a role in propagating the belief in a god who cares about pro-social behavior.

Accordingly, it has been argued that religious belief facilitates prosocial behavior and the formation of larger cooperative groups. ${ }^{\text {xxix }}$ Cultural evolutionary research has shown that larger groups preserve advantageous innovations and foster cultural complexity. ${ }^{x}$ So, if belief in a moralistic god facilitates hyper-social behavior (fairness, altruism, large-group cooperation), then belief in a moralistic god would amount to an evolutionary advantage, and therefore would be propagated.

\section{A Moral Evaluation of Cultural Evolution}


In light of what we have seen about how cultural evolution works, should we think of it as a force that inclines towards morality or immorality? The answer is probably "neither", and "both".

On the one hand, cultural evolutionary mechanisms like the ratchet-effect deserve a morally neutral evaluation. Cultural evolution conduces to the advancement of knowledge and greater levels of productivity and interpersonal connectivity, all of which generates productive and reproductive advantages. But superior technology and social networks are in themselves neither good nor bad. Tools and relationships possess no innate moral status, but rather are morally evaluated on the basis of the use to which they are put. In this sense, cultural evolution in se inclines populations neither towards good nor towards evil.

On the other hand, we have seen that cultural evolution can actually reinforce both positive and negative behavior, functioning as a source of moral inertia. In a negative sense, we have argued that over-imitation, conformity, and normativity reinforce the likelihood that one generation's sinful behavior will be reproduced by the next generation. But in the positive sense, cultural evolution has also favored just, altruistic, and hyper-social behavior. Since fairness, self-sacrifice, and kindness can conduce to group selection, and since imitation and normativity will help reinforce virtuous behavior just as much as vicious behavior, cultural evolution can be seen as a force for good just as much as for evil.

Hyper-Sociality, Free-Loaders, and Rituals

Notwithstanding the undeniable benefits of the hyper-sociality fostered by cultural evolution, it is vulnerable to exploitation by "free-riders." As any economist will explain, large group cooperation can be exploited by individuals inclined to benefit from the group's resources and protection without making a commensurate contribution. ${ }^{x i}$ The study of cultural evolution has argued, however, that ritual behavior helps overcome the free-rider problem.

It may come as a surprise to hear that ritual is a major locus for cultural evolutionary research, but recent study suggests that religious ritual may be embedded in our cultural-evolutionary heritage. ${ }^{\text {xli }}$ Above we described the human tendency towards over-imitation, toward repeating causally opaque actions in anticipation of a productive outcome; this may in fact be a contributing factor in the development of religious rituals. The same human willingness to imitate complex processes with beneficial outcomes (even when we do not understand how a process generates a given outcome), under the pressures of normativity and conformity, also makes humans susceptible to imitating complex processes that may not have an immediately functional outcome, e.g. religious rituals. 
Historically, religious people have often engaged in ritual worship with the belief that doing so will help ensure their material prosperity, appeasing their deity and thereafter returning to labor and the other immanent causes of material prosperity. The supposed connection between the worship and a subsequent good harvest is causally opaque. But the cognitive science of religion has suggested that humans are prone to "hypersensitive agency detection", i.e. perceiving the presence of causal agents even when no agent is present. The so-called "Hypersensitive Agency Detection Device"

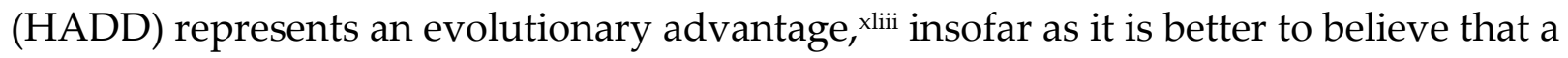
potentially hostile agent is operative, and be wrong, than not to perceive the operation of an agent when one is present. While the evidence is as of yet inconclusive, it is conceivable that the HADD could in fact predispose humans towards religious belief. ${ }^{\text {liv }}$

At any rate, this same tendency could contribute to the development of religious rituals. One could well imagine that rituals arose early in human pre-history as people came to associate non-productive actions with events of good fortune, and thereby concluded that the non-productive action actually caused the fortuitous outcomes, e.g. through securing the blessing of a deity. This is actually part of the way that scholars of ancient Near Eastern religion surmise that the process of ancient divination developed, ${ }^{\text {lv }}$ and it is reasonable to suggest a similar origin for other religious rituals.

While one might expect such rituals to be a drag on productivity, they may actually have helped solve some of the problems of human hyper-sociality. Two components of ritual behavior have garnered serious scientific study and both contribute to pro-social behavior within the ritualistic group. In the first instance, research has suggested that group pro-sociality is strengthened by shared, synchronous movements-movements of matched rhythmic behavior in time (like singing and dancing). ${ }^{x v i}$ Second, shared high arousal states (euphoric and dysphoric) contribute to psychological bonding between group members which can be correlated to increased prosociality within the group. ${ }^{\text {xlvii }}$ What is more, because religious rituals are causally opaque actions that are often costly, they signal that another person shares a commitment to the group's values, which in turn suggests a willingness to work cooperatively with the group. ${ }^{\text {xlviii }}$ As a result, group members can work together as a larger cohesive unit, reaping the benefits of cooperation while diminishing productive drag of free-riders (who would be less likely to participate in costly rituals). These aspects of cultural evolution help provide an account of how human religious practices emerged.

This raises a question of whether one should think that the human tendency towards religious ritual is nothing more than an accident of our over-imitating tendencies and the bonding that results from shared high arousal states, which happen to have beneficial outcomes enabling our hyper-sociality (large group cooperation) and thus human competitiveness. ${ }^{\text {xlix }}$ To put a finer point on it: is the fact that I engage in rituals like the Eucharist and tithing largely a by-product of the fact that it was 
beneficial for my human ancestors to engage in their own ritual activities, insofar as doing so conduced to greater cooperation in large groups? This brings us to our final question in roughing out some of the most important geographical contours for our mapmaking enterprise.

\section{Does Cultural Evolution Account for the Existence of Religion?}

We have seen that the study of cultural evolution provides stimulating accounts different features of religion, ${ }^{1}$ such as: why altruistic behavior flourishes in human society; how hyper-sociality beyond the limits of kin-selection is advantageous for survival; how belief in a moralistic and punitive god fosters hyper-sociality; and how religious rituals contribute to group selection.

In addition, cultural evolution may also help explain the persistence of religious doctrine. Consider the human capacity for teaching and our social biases for conformity and normativity. These features of human cultural evolution, so important for ratcheting and thus cumulative culture, could also help perpetuate an erroneous belief in the existence of a deity and the right way of behaving towards that deity. ${ }^{\mathrm{li}}$ These ideas, once present in the community, would be difficult to root out, given the human tendency to conform to common practice, our capacity for teaching, and the possibility that belief in a just and punishing deity would reinforce beneficial cooperation.

In conjunction, these observations raise the question of whether religious ritual and morality may simply be by-products or exaptations of cultural evolution. Cultural evolution does make it possible to give an atheistic explanation of religious belief and morality. But we should not overlook the fact that an equally plausible account of the same dynamics could be embraced from a religious perspective. One could argue that the mechanisms undergirding cultural evolution make us capable of perceiving the God who really exists; one could contend that God used cultural evolution to generate these attributes precisely for the purpose of enabling and supporting our encounter and sustained relationship with him. Over-imitation or normativity need no more to imperil the legitimacy of my religious rituals and my knowledge of God than they imperil the legitimacy of my quotidian professional habits or my knowledge of Newtonian physics. Just because my bio-cultural evolutionary inheritance enables me to accomplish complex but mundane life tasks and to acquire progressively more-complex knowledge, does not mean that my complex life tasks or knowledge are somehow rendered insignificant. Having the necessary hardware for a task does not delegitimize or falsify the ends to which the hardware is used. So also, having a culturalevolutionary capacity to pursue and know about God (who may or may not exist) does not mean that my relationship with and knowledge of God are necessarily spurious. ${ }^{\text {lii }}$ 
One might counter that those mechanisms identified by cultural evolutionary research do more than just enable religion; perhaps, like a misfiring of the Hypersensitive Agency Detection Device, they actually incline people to adopt and transmit religious behavior as a consequence of human over-imitation (i.e. our willingness to repeat actions without knowing what might be their outcomes, because of a high degree of openness to the possibility that the non-productive behaviors might actually have mysterious beneficial outcomes). This is an important objection. In a similar vein, psychological research indicates that from an early age children are given to "promiscuous teleology", i.e., they are inclined to assign purpose and design to objects and phenomena which adults would consider non-purposive (e.g. rocks are pointy so that animals don't sit on them, or so that animals can scratch themselves when they have an itch). liii Children also have an innate tendency to attribute different life-cycle traits and ways of knowledge to non-human (e.g. supernatural) agents; their inborn psychological hardware is amenable to the possibility of supernatural or divine agents whose lives and actions are not simple anthropomorphizing extrapolations. ${ }^{\text {liv }}$ For these reasons, some psychologists have suggested that children are "intuitive theists"; ; they are naturally amenable and even disposed to the existence and action of supernatural agents in the natural world. In sum, one could argue (reductively) that theism is simply a consequence of our cultural-evolutionary constitution, or at least that our propensity towards teleofunctional explanations of reality would "make notions of purposeful creator beings especially resonant". . $^{\mathrm{vi}}$

Conversely, however, one could see this cultural-evolutionary wiring as amenable to the claims of Christian theology. It stands to reason that a God who desires to be known by people would reasonably (even necessarily) equip them with the sort of neurobiological and cognitive equipment conducive to their encounter with him. ${ }^{\text {.vii }}$ Given the Christian construal of the character and will of God, it would seem incongruous for God not to compose us in such a fashion as to coax and sustain knowledge of and relationship with him. Iviii The mere anthropo-biological facts of cultural evolution do not amount to a metaphysical explanation for the existence of those facts; rather, one must test the facts against different atheistic and religious explanations. There is a difference between efficient and final causes, between a biological process and the philosophical account one gives of that process' significance or purpose, or, to use the language of Richard Swinburne, between scientific and personal explanations. lix

Alister McGrath has argued that Christian theology should not engage with science in order to prove the existence of God. Instead, theology begins from the posture of Christian faith and inquires whether the phenomena of nature cohere with the God made known in Christian revelation. "Natural theology emphasizes the resonance between the framework offered by the Christian faith and observation". . The findings of cultural evolution and cognitive science do not seem to stand in tension with 
a God who desires to be known by humanity (agency detection, promiscuous teleology), to transmit that knowledge across generations (teaching, conformity, normativity), to shape and mobilize humanity in its image (cumulative culture, innovation, cooperation), and to foster love of family and neighbor (altruism and hypersociality). Quite the contrary, it seems reasonable to imagine that the Christian God might use cultural evolution to create beings sensitive to its existence, inclined to perceive its agency, and disposed to act with compassion towards others, even when doing so requires self-sacrifice, treating a stranger as if they were family.

\section{Conclusion}

This article has been an exercise in theological cartography, an attempt to map out the terrain of cultural evolution in order to ascertain whether its seas and topography are diabolical or divine. After these preliminary explorations, there seems to be little need to stamp any portion of the map with the warning hic sunt dracones. There seem to be no more dragons lurking in cultural evolution than there were in the Atlantic in the $15^{\text {th }}$ century. Many portions of the map need filling in, and some of the terrain could prove treacherous should one try to traverse it in an imprudent fashion; cultural evolution might prove perilous, for example, to those who would appeal to an altruistic God-ofthe-Gaps. Similarly, cultural evolution raises intriguing questions about the origins of religious rituals, although those questions are by no means disastrous for Christian faith. Rather, if one is concerned about the apologetic ramifications of cultural evolution, one needs to ask whether those mechanisms are somehow contrary to the character of the God, what purposes God might have for those mechanisms, and whether those purposes provide an account of the cultural-evolutionary phenomena that are as convincing as those offered in a nontheistic framework.

Cultural evolution is undergoing lively exploration today and cartography is always an ongoing task. The first maps created of any terrain make no claims of comprehensiveness, and often reveal more about the concerns of the mapmakers and the culture in which they ply their trade. In this exercise of theological cartography, we do not presume to have provided exhaustive detail; like most early explorers, we sought to map the territory that is currently most relevant to theologians exploring cultural evolution. Just as plate tectonics, tides, volcanic activity, and erosion alter coast lines and even create new islands and continents, the authors expect that this theological cartograph will be refined as scientists explore new terrain. At very least, however, this mapping will help prevent theologians from running aground on some doctrinal shoals, or getting so lost in the scientific unknown that they sail off the edge of the earth. 


\section{Bibliography}

Alexander, Denis. Creation or Evolution: Do We Have to Choose? Oxford: Monarch, 2008.

Alvarez, Sara, Anthony Di Fiore, Jane Champion, Mary Susan Pavelka, Johanna Páez, and Andrés Link.

"Male-Directed Infanticide in Spider Monkeys (Ateles spp.)." Primates 56 (2015): 173-81.

Barrett, Justin L. Cognitive Science, Religion, and Theology: From Human Minds to Divine Minds.

Templeton Science and Religion Series. West Conshohocken, PA: Templeton, 2011.

Barrett, Justin L., Rebekah A. Richet, and Amanda Driesenga. “God's Beliefs versus Mother's: The Development of Nonhuman Agent Concepts." Child Development 72, no. 1 (2001): 50-65.

Bloom, Paul. "Did God Make These Babies Moral? Intelligent Design's Oldest Attack on Evolution is as Popular as Ever." New Republic, January 13, 2014.

https://newrepublic.com/article/116200/moral-design-latest-form-intelligent-design-its-wrong.

Burdett, Emily R.R., and Justin L. Barrett. "The Circle of Life: A Cross-Cultural Comparison of Children's Attribution of Life-Cycle Traits." British Journal of Developmental Psychology 34, no. 2 (2015): 276-90.

Burdett, Michael S. "The Image of God and Human Uniqueness: Challenges from the Biological and Information Sciences." Expository Times 127, no. 1 (2015): 3-10.

Collins, Francis S. The Language of God: A Scientist Presents Evidence for Belief. New York: Free, 2006.

Crisp, Oliver. "On Original Sin." International Journal of Systematic Theology 17, no. 3 (2015): 252-66.

Darwin, Charles. The Descent of Man and Selection in Relation to Sex. New York: Appleton, 1871.

--- On the Origin of Species: By Means of Natural Selection. 6th ed. Auckland, New Zealand: Floating, 1872.

Dawkins, Richard. The God Delusion. New York: Houghton Mifflin, 2006.

Dean, L.G., R.L. Kendal, S.J. Schapiro, B. Thierry, and K.N. Laland. "Identification of the Social and Cognitive Processes Underlying Humand Cumulative Culture." Science 335 (2012): 1114-18.

Deane-Drummond, Celia. The Wisdom of the Liminal: Evolution and Other Animals in Human Becoming. Grand Rapids: Eeerdmans 2014.

Giberson, Karl W., and Francis S. Collins. The Language of Science and Faith. Downer's Grove, IL: IVP, 2011.

Hamilton, W.D. "The Genetical Evolution of Social Behaviour: 1." Journal of Theoretical Biology 7 (1964): 1-16.

Hardin, Russell. (The Free Rider Problem). Interview with Edward N. Zalta, Stanford, 2013.

Harris, Mark. "The Biblical Text and a Functional Account of the Imago Dei." In Finding Ourselves After Darwin: Conversations about the Image of God, Original Sin, and the Problem of Evil, edited by Stanley P. Rosenberg, Michael Lloyd, Benno Van den Toren and Michael J. Burdett. Grand Rapids: Baker Academic, 2018.

Hays, Christopher M. "A Non-Historical Approach: The Universality of Sin without the Originating Sin." In Finding Ourselves After Darwin: Conversations about the Image of God, Original Sin, and the Problem of Evil, edited by Stanley P. Rosenberg, Michael Lloyd, Benno Van den Toren and Michael J. Burdett. Grand Rapids: Baker Academic, 2018.

Hays, Christopher M., and Stephen Lane Herring. "Adam and the Fall." In Evangelical Faith and the Challenge of Historical Criticism, edited by Christopher M. Hays and Christopher B. Ansberry, 2454. Grand Rapids: Baker, 2013.

Hefner, Philip J. The Human Factor: Evolution, Culture, and Religion. Minneapolis: Augsburg Fortress, 1993.

- - . The Human Factor: Evolution, Culture, and Religion. Theology and the Sciences. Minneapolis: Fortress Press, 1993.

Henrich, Joseph. The Secret of our Success: How Culture is Driving Human Evolution, Domesticating Our Species and Making Us Smarter. Princeton: Princeton University Press, 2016. 
Henrich, Joseph, Jean Ensminger, Richard McElreath, Abigail Barr, Clark Barrett, Alexander Bolyanatz, Juan Camilo Cardenas, et al. "Markets, Religion, Community Size, and the Evolution of Fairness and Punishment." Science 327 (2011): 1480-84.

Jong, Jonathan, Christopher Kavanagh, and Aku Visala. "Born Idolators: The Limits of the Philosophical Implications of the Cognitive Science of Religion." Neue Zeitschrift für systematische Theologie und Religionsphilosophie 57, no. 2 (2015): 244-66.

Jong, Jonathan, and Aku Visala. "Evolutionary Debunking Arguments against Theism, Reconsidered." International Journal for Philosophy and Religion 76, no. 3 (2014): 243-58.

Kahane, Guy. "Evolutionary Debunking Arguments." Nous 45 (2011): 103-25.

Kelemen, Deborah. "Are Children 'Intuitive Theists'? Reasoning about Purpose and Design in Nature." Psychogical Science 15, no. 5 (2004): 295-301.

Laland, Kevin N. "Exploring Gene-Culture Interactions: Insights from Handedness, Sexual Selection and Niche-Construction Case Studies." Philosophical Transactions of the Royal Society B: Biological Sciences 363, no. 1509 (2008): 3577-89.

Laland, Kevin N., T. Uller, M. Feldman, K. Sterelny, G. B. Müller, A. Moczek, E. Jablonka, et al. “Does Evolutionary Theory Need a Rethink?" Nature 514, no. 7521 (2014): 161-4.

Legare, Christine H., and Mark Nielsen. "Imitation and Innovation: The Dual Engines of Cultural Learning." Trends in Cognitive Sciences 19, no. 11 (2015): 688-99.

McGrath, Alister E. A Fine-Tuned Universe: The Quest for God in Science and Theology: The 2009 Gifford Lectures. Louisville, KY: Westminster John Knox, 2009.

McKay, Ryan, and Harvey Whitehouse. "Religion and Morality." Psychological Bulletin 141, no. 2 (2014): 447-73.

Mesoudi, Alex. Cultural Evolution: How Darwinian Evolutionary Theory Can Explain Human Culture and Synthesize the Social Sciences. Chicago: University of Chicago Press, 2011.

Mesoudi, Alex, Andrew Whiten, and Kevin N. Laland. "Towards a Unified Science of Cultural Evolution." Behavioral and Brain Sciences 29, no. 4 (2006): 329-47.

Moritz, Joshua M. "Human Uniqueness, the Other Hominids, and "Anthropocentrism of the Gaps"." Zygon 47, no. 1 (2012): 65-96.

Muthukrishna, Michael, Ben W. Shulman, Vlad Vasilescu, and Joseph Henrich. "Sociality Influences Cultural Complexity." Proceedings of the Royal Society B 281 (2013).

Norenzayan, Ara. "The Idea that Launched a Thousand Civilizations." NewScientist, March 17, 2012.

Norenzayan, Ara, and Azim F. Shariff. "The Origin and Evolution of Religious Prosociality." Science 322 (2008): 58-62.

Odling-Smee, John, Douglas H. Erwin, Eric P. Palkovacs, Marcus W. Feldman, and Kevin N. Laland. "Niche Construction Theory: A Practical Guide for Ecologists." The Quarterly Review of Biology 88, no. 1 (2013): 3-28.

Podany, Amanda. The Ancient Near East: A Very Short Introduction. Oxford: Oxford University Press, 2014.

Purzycki, Benjamin Grant, Coren Apicella, Quentin D. Atkinson, Emma Cohen, Rita Anne McNamara, Aiyana K. Willard, Dimitris Xygalatas, Ara Norenzayan, and Joseph Henrich. "Moralistic Gods, Supernatural Punishment and the Expansion of Human Society." Nature 530 (2016): 327-30.

Reddish, Paul, Joseph Bulbulia, and Ronald Fischer. "Does Synchrony Promote Generalized Prosociality?" Religion, Brain \& Behavior 4, no. 1 (2014/01/02 2014): 3-19.

Richerson, Peter J., and Morten H. Christiansen. "Introduction." In Cultural Evolution: Society, Technology, Language, and Religion, edited by Peter J. Richerson and Morten H. Christiansen. Cambridge, MA: MIT Press, 2013.

Sterelny, Kim. Dawkins vs. Gould: Survival of the Fittest. New ed. London: Icon, 2007.

Swinburne, Richard. The Existence of God. $2^{\text {nd }}$ ed. Oxford: Oxford University Press, 2004. 
Tennie, Claudio, Josep Call, and Michael Tomasello. "Racheting up the Rachet: On the Evolution of Cumulative Culture." Philosophical Transactions of the Royal Society B 364 (2009): 2405-15.

Tomasello, Michael. Cultural Origins of Human Cognition. Cambridge: Harvard University Press, 2009.

Van den Toren, Benno. "Co-evolution of Human Nature, Culture and Original Sin." In Finding Ourselves After Darwin: Conversations about the Image of God, Original Sin, and the Problem of Evil, edited by Stanley P. Rosenberg, Michael Lloyd, Benno Van den Toren and Michael J. Burdett. Grand Rapids: Baker Academic, 2018.

- - . "Human Evolution and a Cultural Understanding of Original Sin." Perspectives on Science and Christian Faith 68, no. 1 (2016): 1-10.

Van Huyssteen, J. Wentzel. Alone in the World?: Human Uniqueness in Science and Theology. Grand Rapids: Eerdmans, 2006.

Visala, Aku. "Will the Structural Theory of the Image of God Survive Evolution?". In Finding Ourselves After Darwin: Conversations about the Image of God, Original Sin, and the Problem of Evil, edited by Stanley P. Rosenberg, Michael Lloyd, Benno Van den Toren and Michael J. Burdett. Grand Rapids: Baker Academic, 2018.

Walton, John H. Ancient Near Eastern Thought and the Old Testament. Kindle ed. Grand Rapids: Baker Academic, 2006.

Watson-Jones, Rachel E., and Christine H. Legare. "The Social Functions of Group Rituals." Current Directions in Psychological Science 25, no. 1 (2016): 42-46.

Whitehouse, Harvey, and Jonathan A. Lanman. "The Ties That Bind Us: Ritual, Fusion, and Identification." Current Anthropology 55, no. 6 (2014): 674-95.

Whiten, Andrew, Nicola McGuigen, Sarah Marshall-Pescini, and Lydia M. Hopper. "Emulation, Imitation, Over-imitation and the Scope of Culture for Child and Chimpanzee." Philosophical Transactions of the Royal Society B 364 (2009): 2417-28.

Williams, Patricia A. Doing without Adam and Eve: Sociobiology and Original Sin. Theology and the Sciences. Minneapolis: Fortress, 2001.

Wilson, D.S. "A Theory of Group Selection." Proceedings of the National Academy of Sciences 72, no. 1 (January 1, 1975 1975): 143-46.

\footnotetext{
i The authors are grateful to Jonathan Jong and Emily Reed Burdett for their invaluable scientific consultation. Previous versions of this article were presented to the Red de Ciencia, Filosofía y Religión in Bogotá and at the Biologos Configuring Adam and Eve conference at Kellogg College, Oxford, and we are thankful for the constructive engagement offered on each occasion.

ii Our task is not to provide an exhaustive account of the science and the theology; we focus on the most relevant recent research in cultural evolution that has import for theological anthropology, hamartiology, morality, and the nature of religion and ritual. We also do not aim to be systematic in our treatment of biblical and church historical material. The first maps of any terrain are necessarily partial, and invite further exploration and refinement.

iii Charles Darwin, On the Origin of Species: By Means of Natural Selection, 6th ed. (Auckland, New Zealand: Floating, 1872), 146.

iv See e.g. Kim Sterelny, Dawkins vs. Gould: Survival of the Fittest, New ed. (London: Icon, 2007).

v Kevin N. Laland et al., “Does Evolutionary Theory Need a Rethink?,” Nature 514:7521 (2014): 162; cf. John Odling-Smee et al., “Niche Construction Theory: A Practical Guide for Ecologists," The Quarterly Review of Biology 88:1 (2013): 3-28.
} 
vi Alex Mesoudi, Andrew Whiten, and Kevin N. Laland, "Towards a Unified Science of Cultural Evolution," Behavioral and Brain Sciences 29:4 (2006): 329-47.

vii Kevin N. Laland, “Exploring Gene-Culture Interactions: Insights from Handedness, Sexual Selection and Niche-Construction Case Studies," Philosophical Transactions of the Royal Society B: Biological Sciences 363:1509 (2008): 3577-89.

viii Peter J. Richerson and Morten H. Christiansen, "Introduction," in Cultural Evolution: Society, Technology, Language, and Religion, eds. Peter J. Richerson and Morten H. Christiansen (Cambridge, MA: MIT Press, 2013), 5.

ix Alex Mesoudi, Cultural Evolution: How Darwinian Evolutionary Theory Can Explain Human Culture and Synthesize the Social Sciences (Chicago: University of Chicago Press, 2011), 2-3; cf. Richerson and Christiansen, "Introduction," 3.

× Christine H. Legare and Mark Nielsen, "Imitation and Innovation: The Dual Engines of Cultural Learning," Trends in Cognitive Sciences 19:11 (2015): 688-98.

xi Joseph Henrich, The Secret of our Success: How Culture is Driving Human Evolution, Domesticating Our Species and Making Us Smarter (Princeton: Princeton University Press, 2016).

xii J. Wentzel Van Huyssteen, Alone in the World?: Human Uniqueness in Science and Theology (Grand Rapids: Eerdmans, 2006); Celia Deane-Drummond, The Wisdom of the Liminal: Evolution and Other Animals in Human Becoming (Grand Rapids: Eeerdmans 2014); Joshua M. Moritz, "Human Uniqueness, the Other Hominids, and "Anthropocentrism of the Gaps"," Zygon 47:1 (2012): 65-96; Philip J. Hefner, The Human Factor: Evolution, Culture, and Religion (Minneapolis: Augsburg Fortress, 1993).

xiii Michael Tomasello, Cultural Origins of Human Cognition (Cambridge: Harvard University Press, 2009). xiv Claudio Tennie, Josep Call, and Michael Tomasello, "Racheting up the Rachet: On the Evolution of Cumulative Culture," Philosophical Transactions of the Royal Society B 364 (2009): 2405-15; L.G. Dean et al., "Identification of the Social and Cognitive Processes Underlying Humand Cumulative Culture," Science 335 (2012): 1114-18.

xv See the examples described in Andrew Whiten et al., "Emulation, Imitation, Over-imitation and the Scope of Culture for Child and Chimpanzee," Philosophical Transactions of the Royal Society B 364 (2009): 2424-25.

xvi See Michael S. Burdett, “The Image of God and Human Uniqueness: Challenges from the Biological and Information Sciences," Expository Times 127:1 (2015): 3-10.

xvii Aku Visala, "Will the Structural Theory of the Image of God Survive Evolution?," in Finding Ourselves After Darwin: Conversations about the Image of God, Original Sin, and the Problem of Evil, eds. Stanley P.

Rosenberg, et al. (Grand Rapids: Baker Academic, 2018), forthcoming.

xviii See Mark Harris, "The Biblical Text and a Functional Account of the Imago Dei," in Finding Ourselves After Darwin: Conversations about the Image of God, Original Sin, and the Problem of Evil, eds. Stanley P. Rosenberg, et al. (Grand Rapids: Baker Academic, 2018), forthcoming.

xix See e.g. Patricia A. Williams, Doing without Adam and Eve: Sociobiology and Original Sin, Theology and the Sciences (Minneapolis: Fortress, 2001); Hefner, Human Factor.

xx Benno van den Toren, "Human Evolution and a Cultural Understanding of Original Sin," Perspectives on Science and Christian Faith 68:1 (2016): 1-10; Benno Van den Toren, "Co-evolution of Human Nature, Culture and Original Sin," in Finding Ourselves After Darwin: Conversations about the Image of God, Original Sin, and the Problem of Evil, eds. Stanley P. Rosenberg, et al. (Grand Rapids: Baker Academic, 2018), forthcoming.

xxi See e.g. Sara Alvarez et al., "Male-Directed Infanticide in Spider Monkeys (Ateles spp.)," Primates 56 (2015): 173-81.

xxii Christopher M. Hays and Stephen Lane Herring, "Adam and the Fall," in Evangelical Faith and the Challenge of Historical Criticism, eds. Christopher M. Hays and Christopher B. Ansberry (Grand Rapids: Baker, 2013), 32-52. 
xxiii See further Christopher M. Hays, "A Non-Historical Approach: The Universality of Sin without the Originating Sin," in Finding Ourselves After Darwin: Conversations about the Image of God, Original Sin, and the Problem of Evil, eds. Stanley P. Rosenberg, et al. (Grand Rapids: Baker Academic, 2018).

xxiv Oliver Crisp, “On Original Sin,” International Journal of Systematic Theology 17:3 (2015): 252-66.

xxv Hays and Herring, "Adam and the Fall," 24-54; Hays, "A Non-Historical Approach," .

xxvi Quasi-biological language (for instance, "infection"; see e.g. Augustine, City of God, 14.16, 21) has often

been used to describe how sin is transmitted between generations. The role played by genes in

transmitting sinful tendencies does lend credibility to the Tridentine/Augustinian formulation that original sin is transmitted generatione, non imitatione (that is, "by generation, not by imitation"; Council of Trent, Decretum super peccato originali, 3; cf. Augustine, Pecc. mer. 19-20). Nonetheless, cultural evolution may counterbalance the Tridentine formulation in a more Pelagian direction, insofar as cultural evolution focuses on how cultural practices (including practices we would denominate as sinful) are transmitted by "imitation." Perhaps the balance of evidence would suggest a reformulation of the Tridentine phrase along the lines of generatione et imitatione!

xxvii See e.g. Denis Alexander, Creation or Evolution: Do We Have to Choose? (Oxford: Monarch, 2008), 236-39, 55.

xxviii Charles Darwin, The Descent of Man and Selection in Relation to Sex (New York: Appleton, 1871), 156-57. Darwin, however, also foresaw how altruistic behavior would facilitate group selection; ibid., 159-60.

xxix W.D. Hamilton, "The Genetical Evolution of Social Behaviour: 1," Journal of Theoretical Biology 7 (1964): $1-16$.

xxx Francis S. Collins, The Language of God: A Scientist Presents Evidence for Belief (New York: Free, 2006), 27. xxxi Ibid., 29.

xxxii Paul Bloom, “Did God Make These Babies Moral? Intelligent Design's Oldest Attack on Evolution is as Popular as Ever," New Republic, January 13, 2014..

xxxiii Collins, Language of God, 193-94.

xxxiv To his credit, Collins recognized the vulnerability of his position in a more recent book; Karl W. Giberson and Francis S. Collins, The Language of Science and Faith (Downer's Grove, IL: IVP, 2011), 143. xxxv Group selection simply denotes the way in which the cooperative or even self-sacrificial actions of individual group members can provide a survival advantage to the group as a whole, even if the individual organism itself does not personally gain a reproductive advantage; D.S. Wilson, "A Theory of Group Selection," Proceedings of the National Academy of Sciences 72:1 (1975): 143-46.

xxxvi Ara Norenzayan, "The Idea that Launched a Thousand Civilizations," NewScientist, March 17, 2012, $42-44$..

xxxvii Ara Norenzayan and Azim F. Shariff, "The Origin and Evolution of Religious Prosociality," Science 322 (2008): 58-62.

xxxviii Benjamin Grant Purzycki et al., "Moralistic Gods, Supernatural Punishment and the Expansion of Human Society," Nature 530 (2016): 327-30.

xxxix Joseph Henrich et al., "Markets, Religion, Community Size, and the Evolution of Fairness and Punishment," Science 327 (2011): 1480-84.

xl Michael Muthukrishna et al., "Sociality Influences Cultural Complexity," Proceedings of the Royal Society B 281 (2013).

xli See e.g. Russell Hardin (The Free Rider Problem), interview with Edward N. Zalta, Stanford, 2013.

xlii Rachel E. Watson-Jones and Christine H. Legare, "The Social Functions of Group Rituals," Current Directions in Psychological Science 25:1 (2016): 42-46.

xliii Justin L. Barrett, Cognitive Science, Religion, and Theology: From Human Minds to Divine Minds, Templeton Science and Religion Series (West Conshohocken, PA: Templeton, 2011), 100-02.

xliv McKay and Whitehouse, "Religion and Morality," 455. 
xlv Amanda Podany, The Ancient Near East: A Very Short Introduction (Oxford: Oxford University Press, 2014), 102; for an introduction to "deductive divination", see John H. Walton, Ancient Near Eastern Thought and the Old Testament, Kindle ed. (Grand Rapids: Baker Academic, 2006), 249-63.

xlvi Paul Reddish, Joseph Bulbulia, and Ronald Fischer, “Does Synchrony Promote Generalized Prosociality?," Religion, Brain \& Behavior 4:1 (2014): 3-19.

xlvii Harvey Whitehouse and Jonathan A. Lanman, "The Ties That Bind Us: Ritual, Fusion, and Identification," Current Anthropology 55:6 (2014): 674-95. xlviii Watson-Jones and Legare, "Social Functions," 42-46.

xlix Cf. McKay and Whitehouse, "Religion and Morality," 457, 63-64.

${ }^{1}$ See further ibid., 454-58.

li Richard Dawkins's construal of religion as a "by-product" functions along these lines; Richard Dawkins, The God Delusion (New York: Houghton Mifflin, 2006), 203-08.

lii So-called "evolutionary debunking arguments" for religious and moral epistemology abound (see e.g. Guy Kahane, “Evolutionary Debunking Arguments," Nous 45 (2011): 103-25). The authors, however, agree with the argument that the deliverances of our cognitive faculties should not be discarded because of naturalistic and evolutionary accounts, but rather ought to be considered "innocent until proven guilty" (Barrett, Cognitive Science, Religion, and Theology: From Human Minds to Divine Minds, 89-95; further, Jonathan Jong and Aku Visala, "Evolutionary Debunking Arguments against Theism, Reconsidered," International Journal for Philosophy and Religion 76:3 (2014): 243-58).

liii Deborah Kelemen, "Are Children 'Intuitive Theists'? Reasoning about Purpose and Design in Nature," Psychogical Science 15:5 (2004): 295-301.

liv Justin L. Barrett, Rebekah A. Richet, and Amanda Driesenga, "God's Beliefs versus Mother's: The Development of Nonhuman Agent Concepts," Child Development 72:1 (2001): 50-65; Emily R.R. Burdett and Justin L. Barrett, "The Circle of Life: A Cross-Cultural Comparison of Children's Attribution of LifeCycle Traits," British Journal of Developmental Psychology 34:2 (2015): 276-90.

Iv Kelemen, "Are Children 'Intuitive Theists'? Reasoning about Purpose and Design in Nature,". lvi McKay and Whitehouse, "Religion and Morality," 456.

lvii Cf. Barrett, Cognitive Science, Religion, and Theology: From Human Minds to Divine Minds, 161-63.

lviii Although see Jonathan Jong, Christopher Kavanagh, and Aku Visala, “Born Idolators: The Limits of the Philosophical Implications of the Cognitive Science of Religion," Neue Zeitschrift für systematische Theologie und Religionsphilosophie 57:2 (2015): 244-56.

lix Richard Swinburne, The Existence of God, $2^{\text {nd }}$ ed. (Oxford: Oxford University Press, 2004), 23-51.

1x Alister E. McGrath, A Fine-Tuned Universe: The Quest for God in Science and Theology: The 2009 Gifford Lectures (Louisville, KY: Westminster John Knox, 2009), 28. 